\title{
PERBANDINGAN WAKTU TUNGGU DAN KEPUASAN PASIEN RAWAT JALAN RSUD RATU ZALECHA MARTAPURA
}

\author{
Miftakhul Jannah', Ichsan Rizany ${ }^{2 *}$, Herry Setiawan ${ }^{3}$ \\ 1,2,3Program Studi Ilmu Keperawatan Fakultas Kedokteran, Universitas Lambung Mangkurat \\ *) ichsan.r.psik@ulm.ac.id
}

\begin{abstract}
Abstrak
Waktu tunggu yang lama adalah salah satu komponen yang menyebabkan ketidakpuasan pasien. Metode penelitian ini menggunakan penelitian eksperimental dengan desain post test only control group. Jumlah sampel adalah 70, instrumen kuesioner kepuasan dan lembar observasi waktu tunggu. Uji analisis menggunakan uji-T dan uji Mann Whitney. Lokasi penelitian di RSUD Ratu Zalecha Martapura. Hasil yang didapatkan dari penelitian ini yaitu kepuasan rata-rata pasien online adalah 107,31 dan pasien offline adalah 105,89. Ada perbedaan dalam kepuasan pasien online dan pasien offline $(p=0,001)$. Waktu tunggu rata-rata untuk pasien online adalah 50,3 menit dan pasien offline adalah 165,46 menit. Ada perbedaan waktu tunggu untuk pasien online dan pasien offline di rawat jalan di Rumah Sakit Ratu Zalecha Martapura ( $p$-value 0,003). Ada perbedaan kepuasan pasien rawat jalan sebesar 16,08. Kepuasan pasien online dan waktu tunggu telah mencapai kepuasan SPM (90\%) dan waktu tunggu $<60$ menit sementara kepuasan offline belum mencapai SPM.
\end{abstract}

Kata Kunci : Waktu tunggu, Kepuasan Pasien, Rawat Jalan

\begin{abstract}
Comparison of Waiting Time and Satisfaction of Road Patients RSUD Ratu Zalecha Martapura. Long waiting time is one component that causes patient dissatisfaction. This research method uses experimental research with a post test only control group design. The number of samples was 70, the satisfaction questionnaire instrument and the waiting time observation sheet. The analysis test uses the T-test and Mann Whitney test. The research location was at Ratu Zalecha Martapura Regional Hospital. The results obtained from this study are the average satisfaction of online patients is 107.31 and offline patients is 105.89. There was a difference in online patient satisfaction and offline patients $(p=0.001)$. The average waiting time for online patients is 50.3 minutes and offline patients is 165.46 minutes. There is a difference in waiting time for online patients and offline patients in outpatient care at Ratu Zalecha Martapura Hospital ( $p$-value 0.003). There is a difference in outpatient satisfaction by 16.08. Online patient satisfaction and waiting time have achieved SPM satisfaction (90\%) and waiting time $<60$ minutes while offline satisfaction has not yet reached SPM.
\end{abstract}

Keyword : Waiting time, patient satisfaction, outpatient

\section{Pendahuluan}

Panjangnya antrian menyebabkan waktu tunggu di IRJA yang lama. Waktu tunggu adalah adalah waktu untuk memperoleh pelayanan rawat jalan dimulai dari loket pendaftaran hingga ke ruang pemeriksaaan yang dipergunakan oleh pasien. Di Indonesia waktu tunggu diatur oleh Kemenkes berdasarkan standar pelayanan minimal. SPM waktu tunggu di rawat jalan yang diatur Kemenkes Nomor 129/Menkes/SK//II/2008 yaitu $<60$ menit atau sama 60 menit. Waktu tunggu yang panjang dapat menyebabkan ketentraman pasien terganggu dan berdampak pada rasa puas pasien di waktu yang akan datang (Permana, 2018). 
Berdasarkan penelitian Laeliyah (2017) didapatkan hasil bahwa waktu menunggu pelayanan di rawat jalan $>60$ menit 49 orang sebesar 70,18 menit (Laeliyah \& Subekti, n.d.) Berdasarkan penelitian dari (Dewi, 2015) waktu tunggu pendaftaran pasien di IRJA 51 responden (53,7\%) kategori cepat, sebaliknya responden dalam waktu tunggu yang lama terdapat 44 responden (Dewi, 2015).

Kepuasan pasien merupakan kejelasan diantara apa yang diinginkan dan diharapkan pasien dengan baiknya sebuah penyediaan jasa dan kesan yang diterima atas kejelasan perawatan yang didapatkan (Anggrianni et al., 2016). Hal yang terpenting bagi pasien salah satunya yaitu kepuasan, ketika pasien tidak senang dengan jasa yang disediakan pasien tidak berkenan memperoleh lagi jasa tersebut dan akan mencari penyediaan jasa yang lain (Supartiningsih, 2017). Salah satu faktor yang dapat berpengaruh terhadap kepuasan pasien yaitu bagusnya sebuah penyediaan jasa yang dapat mempengaruhi nilai keutuhan sebuah pelayanan sehingga memunculkan perasaan puas dalam diri pasien (Munawir, 2018).

Beberapa penelitian tentang kepuasan waktu tunggu didapatkan hasil dari penelitian (Rensiner et al., 2018) didapatkan hasil kualitas pelayanan waktu tunggu sebesar 48,96\% (Rensiner et al., 2018). Pada penelitian (Pranatha et al., 2018) didapatkan hasil penelitian kepuasan terkait pelayanan 35 orang responden yang menerangkan perawat mempunyai perhatian khusus kepada pasien, responden sebanyak $(71,4 \%)$ menganggap puas (Pranatha et al., 2018).
Rumah sakit mencoba untuk melakukan perbaikan waktu tunggu dengan menggunakan sistem online. Berdasarkan hasil studi pendahuluan, jumlah pasien yang menggunakan sistem online di Rumah Sakit sebanyak 300 orang perbulan. Namun, penelitian tantang perbandingan pasien dengan pendaftaran online dan offline masih belum banyak.

Tujaun penelitian ini adalah guna mengetahui perbandingan waktu tunggu dan kepuasan pasien rawat jalan RSUD Ratu Zalecha Martapura.

\section{Metode}

Metode penelitian ini menggunakan penelitian eksperimental dengan desain kelompok kontrol posttest only. Jumlah sampel adalah 70, dengan kriteria inklusi yaitu pasien rawat jalan dari pendaftaran sampai pemeriksaan dokter, pasien yang sudah pernah berobat minimal satu kali, pasien bersedia berpartisipasi pada penelitian, pasien yang berumur $\geq 19$ tahun, pasien bisa menulis dan membaca, pasien dapat berkomunikasi dengan baik. Ditetapkan 35 sampel pasien yang akan dimasukkan pada kelompok perlakuan dan kontrol sehingga jumlah sampel minimal yaitu 70 responden.

Instrumen kuesioner kepuasan dan lembar observasi waktu tunggu yaitu untuk instrumen kepuasan pasien menggunakan kuesioner kepuasan yag terdiri dari 27 pernyataan yang diambil dari kuesioner (Rizany, 2019) dan telah dilaksanakan uji validitas. Skala yang dipakai dalam kuesioner kepuasan pasien yaitu skala likert dengan skor nilai 1-5 dari sangat tidak puas hingga puas. Hasil dari pernyataan responden tersebut diberi nilai tertinggi dan nilai 
terendah, lalu dibagi menjadi dua kategori range. Instrumen kepuasan pasien ini diperoleh dari (Rizany, 2019), instrumen ini memiliki nilai validitas $r$ hitung $>\mathrm{t}$ tabel $(0,407-0,868>0,361)$ untuk semua pernyataan di kuesioner pernyataan dan reliabilitis sebesar 0,976 sudah baku tidak perlu lagi dilaksanakan uji validitas dan reliabilitas.

Uji analisis menggunakan uji-T dan uji Mann Whitney. Lokasi penelitian di IRJA RSUD Ratu Zalecha Martapura. Uji layak etik dilaksanakan di komite etik di IRJA 51 responden $(53,7 \%)$ kategori cepat, sebaliknya responden dalam waktu tunggu yang lama terdapat 44 responden (Dewi, 2015).

Kepuasan pasien merupakan kejelasan diantara apa yang diinginkan dan diharapkan pasien dengan baiknya sebuah penyediaan jasa dan kesan yang diterima atas kejelasan perawatan yang didapatkan (Anggrianni et al., 2016). Hal yang terpenting bagi pasien salah satunya yaitu kepuasan, ketika pasien tidak senang dengan jasa yang disediakan pasien tidak berkenan memperoleh lagi jasa tersebut dan akan mencari penyediaan jasa yang lain (Supartiningsih, 2017). Salah satu faktor yang dapat berpengaruh terhadap kepuasan pasien yaitu bagusnya sebuah penyediaan jasa yang dapat mempengaruhi nilai keutuhan sebuah pelayanan sehingga memunculkan perasaan puas dalam diri pasien (Munawir, 2018).

Beberapa penelitian tentang kepuasan waktu tunggu didapatkan hasil dari penelitian (Rensiner et al., 2018) didapatkan hasil kualitas pelayanan waktu tunggu sebesar 48,96\% (Rensiner et al., 2018). Pada penelitian (Pranatha et al., 2018) didapatkan hasil penelitian kepuasan terkait pelayanan 35 orang responden yang menerangkan perawat mempunyai perhatian khusus kepada pasien, responden sebanyak $(71,4 \%)$ menganggap puas (Pranatha et al., 2018). Rumah sakit mencoba untuk melakukan perbaikan waktu tunggu dengan menggunakan sistem online. Berdasarkan hasil studi pendahuluan, jumlah pasien yang menggunakan sistem online di Rumah Sakit sebanyak 300 orang perbulan. Namun, penelitian tantang perbandingan pasien dengan pendaftaran online dan offline masih belum banyak.

Tujaun penelitian ini adalah guna mengetahui perbandingan waktu tunggu dan kepuasan pasien rawat jalan RSUD Ratu Zalecha Martapura.

\section{Metode}

Metode penelitian ini menggunakan penelitian eksperimental dengan desain kelompok kontrol posttest only. Jumlah sampel adalah 70, dengan kriteria inklusi yaitu pasien rawat jalan dari pendaftaran sampai pemeriksaan dokter, pasien yang sudah pernah berobat minimal satu kali, pasien bersedia berpartisipasi pada penelitian, pasien yang berumur $\geq 19$ tahun, pasien bisa menulis dan membaca, pasien dapat berkomunikasi dengan baik. Ditetapkan 35 sampel pasien yang akan dimasukkan pada kelompok perlakuan dan kontrol sehingga jumlah sampel minimal yaitu 70 responden.

Instrumen kuesioner kepuasan dan lembar observasi waktu tunggu yaitu untuk instrumen kepuasan pasien menggunakan kuesioner kepuasan yag terdiri dari 27 pernyataan yang diambil dari kuesioner (Rizany, 2019) dan telah dilaksanakan uji validitas. Skala yang 
dipakai dalam kuesioner kepuasan pasien yaitu skala likert dengan skor nilai 1-5 dari sangat tidak puas hingga puas. Hasil dari pernyataan responden tersebut diberi nilai tertinggi dan nilai terendah, lalu dibagi menjadi dua kategori range. Instrumen kepuasan pasien ini diperoleh dari (Rizany, 2019), instrumen ini memiliki nilai validitas $r$ hitung $>\mathrm{t}$ tabel $(0,407-0,868>0,361)$ untuk semua pernyataan di kuesioner pernyataan dan reliabilitis sebesar 0,976 sudah baku tidak perlu lagi dilaksanakan uji validitas dan reliabilitas.

Uji analisis menggunakan uji-T dan uji Mann Whitney. Lokasi penelitian di IRJA RSUD Ratu Zalecha Martapura. Uji layak etik dilaksanakan di komite etik

\section{Hasil}

Karakteristik variabel disajikan pada tabel berikut:

Tabel.1 Distribusi frekuensi karakteristik responden

\begin{tabular}{llllc}
\hline & Mean & Median & SD & Min-Max \\
\hline Umur (online) & 38,14 & 39,00 & 8,153 & $22-57$ \\
\hline Umur (offline) & 39,29 & 40,00 & 12,536 & $19-64$ \\
\hline
\end{tabular}

Berdasarkan memperlihatkan bahwa karakteristik responden berdasarkan usia pasien di Rawat Jalan RSUD Ratu Zalecha Martapura yang terbanyak pada pasien online yaitu pada umur 39 tahun dengan sebaran
Tabel .2 Distribusi frekuensi karakteristik responden jenis kelamin

\begin{tabular}{|c|c|c|c|c|}
\hline \multirow{2}{*}{ No. Jenis Kelamin } & \multicolumn{2}{|c|}{ Pasien Online } & \multicolumn{2}{|c|}{ Pasien Offline } \\
\hline & $\mathrm{n}$ & $\%$ & $\mathrm{n}$ & $\%$ \\
\hline 1. Laki-laki & 20 & 57,1 & 13 & 37,1 \\
\hline 2. Perempuan & 15 & 42,9 & 22 & 62,9 \\
\hline Total & 35 & 100 & 35 & 100 \\
\hline No Pendidikan & $\begin{array}{c}\text { Pasi } \\
n\end{array}$ & $\begin{array}{c}\text { online } \\
\%\end{array}$ & $\begin{array}{c}\text { Pasie } \\
n\end{array}$ & $\begin{array}{c}\text { noffline } \\
\%\end{array}$ \\
\hline 1. $\quad$ SD sederajat & 0 & 0,0 & 8 & 22,9 \\
\hline 2. $\quad$ SMP sederajat & 6 & 17,1 & 7 & 20,0 \\
\hline 3. SMA sederajat & 24 & 68,6 & 14 & 40,0 \\
\hline 4. $\quad$ Sarjana (S1) & 5 & 14,3 & 6 & 17,1 \\
\hline Total & 35 & 100,0 & 35 & 100,0 \\
\hline
\end{tabular}




\begin{tabular}{|c|c|c|c|c|}
\hline \multirow{2}{*}{\multicolumn{2}{|c|}{ No Pendidikan }} & \multicolumn{2}{|c|}{ Pasien online } & ffline \\
\hline & & $\mathrm{n}$ & $\%$ & $\%$ \\
\hline
\end{tabular}

\begin{tabular}{llccrc}
\hline 5. & SD sederajat & 0 & 0,0 & 8 & 22,9 \\
\hline 6. & SMP sederajat & 6 & 17,1 & 7 & 20,0 \\
\hline 7. & SMA sederajat & 24 & 68,6 & 14 & 40,0 \\
\hline 8. & Sarjana (S1) & 5 & 14,3 & 6 & 17,1 \\
\hline & Total & 35 & 100,0 & 35 & 100,0 \\
\hline \multirow{2}{*}{ No. } & Pekerjaan & Pasien & Online & Pasien Offline \\
& & $\mathrm{n}$ & $\%$ & $\mathrm{n}$ & $\%$ \\
\hline 1. & PNS & 4 & 11,4 & 0 & 0,0 \\
\hline 2. & Karyawan Swasta & 8 & 22,9 & 2 & 5,7 \\
\hline 3. & Guru & 0 & 0,0 & 4 & 11,4 \\
\hline 4. & Pedagang & 5 & 14,3 & 3 & 8,6 \\
\hline 5. & Nelayan & 0 & 0,0 & 1 & 2,9 \\
\hline 6. & Pelajar/Mahasiswa & 1 & 2,9 & 4 & 11,4 \\
\hline 7. & Pekerjaan lainya (IRT) & 17 & 48,5 & 21 & 60,0 \\
\hline & Total & 35 & 100,0 & 35 & 100,0 \\
\hline
\end{tabular}

Berdasarkan Tabel. 2 menunjukan bahwa karakteristik responden berdasarkan jenis kelamin pasien di IRJA RSUD Ratu Zalecha Martapura yang terbanyak pada pasien online yaitu Laki-laki sebesar 20 orang $(57,1 \%)$ dan pada pasien offline yaitu mayoritas perempuan sebesar 22 orang (62,9\%). Karakteristik responden berdasarkan pendidikan pasien di IRJA RSUD Ratu Zalecha Martapura yang terbanyak terdapat pada pasien online yaitu yang terbanyak SMA/Sederajat sebesar 24 orang $(68,6 \%)$ dan pada pasien offline terbanyak yaitu SMA/Sederajat sebesar 14 orang $(40,0 \%)$. Karakteristik responden berdasarkan pekerjaan pasien di Rawat Jalan RSUD Ratu Zalecha Martapura yang terbanyak pada pasien online yaitu pekerjaan lainya sebanyak 17 orang $(48,5)$ dan pada pasien offline paling banyak yaitu pekerjaan lainya sebanyak 21 orang (60\%).

Tabel.3 Distribusi frekuensi kepuasan pasien

\begin{tabular}{lcccc}
\hline Variabel Kepuasan & Mean & Median & Standar Deviasi & Min-Max \\
& & & & \\
\hline Pasien Online & 107,31 & 108,00 & 0,832 & $105-108$ \\
\hline Pasien Offline & 105,89 & 106,00 & 3,771 & $97-121$ \\
\hline
\end{tabular}


Berdasarkan pada Tabel.3 memperlihatkan bahwa kepuasan pasien di IRJA RSUD Ratu Zalecha Martapura pada pasien online kepuasan pasien rata rata sebesar 107,31 (99,37\%) dengan nilai terendah yaitu $105,00 \mathrm{dn}$ nilai tertinggi 108,00 dan pada pasien offline kepuasan pasien rata-rata sebesar $105,89(87,51 \%)$ dengan nilai terendah yaitu 97 dan tertinggi 121.

Tabel.4 Nilai rata-rata kepuasan pasien (online) di RSUD Ratu Zalecha Martapura

\begin{tabular}{llccc}
\hline $\begin{array}{l}\text { Parameter } \\
\text { Online }\end{array}$ & Mean & Min-Max & $\begin{array}{c}\text { Standar } \\
\text { Deviasi }\end{array}$ & CI 95\% \\
\hline Tangibels & $31,49(98,41 \%)$ & $30-32$ & 0,658 & $31,26-31,71$ \\
\hline Reliability & $16,00(100,00 \%)$ & $16-16$ & 0,000 & - \\
\hline Responsiveness & $15,89(99,31 \%)$ & $15-16$ & 0,323 & $15,77-16,00$ \\
\hline Assurance & $20,00(100,00 \%)$ & $20-20$ & 0,000 & - \\
\hline Emphaty & $23,97(99,87 \%)$ & $23-24$ & 0,169 & $23,91-24,03$ \\
\hline
\end{tabular}

Tabel.4 memperlihatakan bahwa didapatkan hasil nilai rata-rata kepuasan pasien online dengan komponen tertinggi Reliability dan Assurancedengan

presentase 100,00\% dan hasil terendah dengan komponen responsiveness dengan presentase 99,31\%

Tabel.5 Nilai rata-rata kepuasan pasien (ofline) di RSUD Ratu Zalecha Martapura

\begin{tabular}{lcccc}
\hline $\begin{array}{l}\text { Parameter } \\
\text { Offline }\end{array}$ & Mean & Min-Max & $\begin{array}{c}\text { Standar } \\
\text { Deviasi }\end{array}$ & CI 95\% \\
\hline Tangibels & $31,06(91,35 \%)$ & $27-24$ & 0,658 & $30,52-31,60$ \\
\hline Reliability & $15,60(78,00 \%)$ & $13-20$ & 0,000 & $15,19-16,01$ \\
\hline Responsiveness & $15,83(98,94 \%)$ & $15-16$ & 0,323 & $15,70-15,96$ \\
\hline Assurance & $19,86(90,27 \%)$ & $18-22$ & 0,000 & $19,65-20,06$ \\
\hline Emphaty & $23,60(78,67 \%)$ & $19-30$ & 1,519 & $23,08-24,12$ \\
\hline
\end{tabular}

Tabel.5 menunjukkan bahwa didapatkan hasil nilai rata-rata kepuasan pasien online dengan komponen
Responsiveness15,83 (98,94 \%) dan hasil terendah dengan komponen Emphaty 23,60 (78,67 \%). 
Tabel.6 Distribusi frekuensi Waktu Tunggu Pelayanan Pasien

\begin{tabular}{lcccc}
\hline Variabel Waktu Tunggu & Mean & Median & Standar Deviasi & Min-Max \\
\hline Pasien Online & 50,03 & 48,00 & 31,167 & $1-115$ \\
\hline Pasien Offline & 165,46 & 166,00 & 51,928 & $28-282$ \\
\hline
\end{tabular}

*Keterangan satuan : menit

Berdasarkan pada tabel 6 menunjukkan bahwa waktu tunggu pasien di IRJA RSUD Ratu Zalecha Martapura pada pasien online waktu tunggu pasien rata rata sebesar 50,3 menit dengan waktu tunggu terendah yaitu 1 menit dan tertinggi 115 menit. Pada pasien offline waktu tunggu pasien rata-rata sebesar 165,46 menit dengan nilai terendah yaitu 28 menit dan tertinggi 282 menit.

Tabel.7 Hasil analisis perbandingan kepuasan pasien rawat jalan

\begin{tabular}{lccccc}
\hline Variabel & $\mathrm{n}$ & Mean & $\mathrm{SD}$ & Selisih Mean & $\mathrm{p}$-value \\
\hline Kepuasan pasien online & 35 & 43,54 & 524,00 & & \\
\cline { 1 - 4 } Kepuasan pasien offline & 35 & 27,46 & 961,00 & 16,08 & 0,001 \\
\hline
\end{tabular}

Hasil analisis statisti uji Mann Whitney didaptakan $(p=0,001)$ maka $\mathrm{H}_{0}$ ditolak yang memiliki arti terdapat perbedaan kepuasan yang signifikan antar kelompok pasien online dan kelompok pasien offline di IRJA RSUD Ratu Zalecha Martapura.

Tabel.8 Hasil analisis perbandingan waktu tunggu pasien

\begin{tabular}{|c|c|c|c|c|}
\hline Variabel Waktu Tunggu & Mean & SD & Selisih Mean & $\mathrm{p}$-value \\
\hline Online & 50,03 & 31,167 & \multirow{2}{*}{115,43} & \multirow{2}{*}{0,003} \\
\hline Offline & 165,46 & 51,928 & & \\
\hline
\end{tabular}

Hasil analisis statistik uji $\mathrm{T}$ diperoleh $\mathrm{p}$-value $(0,003)$ sehingga $\mathrm{H}_{0}$ ditolak berarti ada perbedaan waktu tunggu pelayanan yang signifikan antar kelompok pasien online dan kelompok pasien offline. 


\section{Pembahasan}

Berdasarkan (Suwaryo \& Yuwono, 2017) mengemukakan pada usia produktif merupakan usia yang paling berperan dan memiliki aktivitas yang padat serta memiliki kemampuan kognitif yang baik. Usia seseorang juga mempengaruhi terhadap daya tangkap dan pola pikir seseorang. Semakin bertambah usia akan semakin berkembang pula daya tangkap dan pola pikirnya, sehingga pengetahuan yang diperolehnya semakin baik (Suwaryo \& Yuwono, 2017).

Perbedaan jenis kelamin dapat memberikan sebuah pemikiranyang berbeda yang berpengaruh pada wawasan serta sikap seseorang yang berbeda tentunya perempuan dan lakilaki Dalam penelitian (Uma, 2017) mengemukakan bahwa laki-laki mampu menyesuaikan diri dengan berbagai macam kondisi untuk mengubah keadaan, fleksible dalam memecahkan masalah, dan mempunyai sikap optimis dibandingkan perempuan. Menurut (Guyton, 2004) bahwa perempuan lebih rentan terkena penyakit karena gaya hidup kurang aktif berolahraga dibandingkan laki-laki.

Berdasarkan penelitian (Ar-rasily \& Dewi, 2016) menyatakan pendidikan adalah suatu kegiatan atau proses pembelajaran untuk mengembangkan atau meningkatkan kemampuan tertentu sehingga sasaran pendidikan itu dapat berdiri sendiri. Tingkat pendidikan turut pula menentukan mudah tidaknya seseorang dalam menyerap dan memahami pengetahuan yang mereka peroleh, pada umumnya semakin tinggi pendidikan seseorang semakin baik pula pengetahuanya (Listiani, 2017)Dilihat dari data yang dikumpulkan bahwa dominan pekerjaan responden yaitu sebagai ibu rumah tangga. Pekerjaan seseorang dapat mempengaruhi gaya hidup serta jumlah penghasilan yang digunakan dalam memenuhi kebutuhan. Menurut Zaini dalam Stefan dkk. (2013) menunjukkan bahwa seseorang yang bekerjamemiliki harapan yang lebih tinggi daripada yang tidak bekerja (Stefan et al., 2013).

Pada dimensi kepuasan pendaftaran online menunjukkan bahwa didapatkan hasil nilai rata-rata kepuasan pasien online dengan komponen tertinggi yaitu dimensi kehandalan (reliability) dan dimensi jaminan (assurance) dengan presentase $\quad 100,00 \%$ Menurut (Muninjaya, 2011) mengatakan bahwa dari kelima dimensi kepuasan yang dinilai sebagai salah satu dimensi yang terpenting oleh konsumen di berbagai industri jasa yakni dimensi kehandalan (reliability). Dalam hal konsumen dalam jasa pelayanan kesehatan sebagai konsumen jasa, dimensi ini dapat menjadi gambaran yakni berupa pelayanan pemeriksaan serta pengobatan yang didapatkan dengan lekas, pelayanan yang jelas dan tidak berputar-putar, serta ketepatan dalam tindakan, dimensi ini memiliki peran penting terhadap pelayanan yang mereka dapatkan hal ini dapat berdampak besar terhadap faktor kepuasan (Muninjaya, 2011). 


\section{Pada dimensi kepuasan} pendaftaran offline menunjukkan bahwa didapatkan hasil nilai rata-rata kepuasan pasien offline dengan komponen tertinggidaya tanggap (Responsiveness) dengan presentase 98,94\%. Menurut (Kuntoro \& Istiono, 2017) dimensi responsiveness lebih berfokus kepada apa yang diinginkan oleh klien yaitu menerima pengaduan, serta masalah yang dikeluhkan oleh konsumen, selalu bersedia memberikan pelayanan dengan tepat guna memenuhi apa yang diperlukan oleh klien, kesediaan penyedia jasa apalagi staffnya guna menolong juga memberikan pelayanan yang tepat sesuai kebutuhan klien dengan informasi yang mudah dimengerti.

Dengan hasil rata-rata waktu tunggu pada pasien online yaitu sebesar 50,3 menit dengan waktu tunggu terendah yaitu 1 menit dan tertinggi 115 menit. Waktu tunggu pada pasien offline rata-rata sebesar 165,46 menit dengan nilai terendah yaitu 28 menit dan tertinggi 282 menit. Pada beberapa poli rawat jalan ada pelayanan yang cepat ada juga yang lambat hal ini dikarenakan jumlah antrian yang banyak dan juga dokter yang terkadang belum ada di ruangan seperti di poli saraf, jantung dan penyakit dalam yang memiliki antrian lebih banyak dibanding poli lain, sedangkan pada poli gigi, poli jiwa, kulit dan kelamin, dan THT memiliki waktu tunggu lebih cepat dikarenakan tidak terlalu banyak antrian. Waktu Tunggu Rawat Jalan yang dialami seluruh sampel pasien pada penelitian ini adalah 66,58 menit, yang melebihi standard yang telah ditetapkan berdasarkan Keputusan No.129/Menkes/SK/II/2008 tentang SPM di IRJA yaitu $\leq 60$ menit (Kemenkes, n.d.).

Peneliti telah melakukan hasil analisis data memakai uji statistik mann whitney yang menunjukkan terdapat perbandingan kepuasan pasien rawat jalan yaitu antara pasien online dan pasien offline menunjukan didaptakan hasil signifikan $(p=0,001)$ yang berarti keputusan $\mathrm{H}_{1}$ diterima dan $\mathrm{H}_{0}$ ditolak berarti terdapat perbedaan kepuasan yang signifikan antara pasien rawat jalan online dan offline. Dari hasil penelitian mendapatkan selisih perbandingan kepuasan pasien di IRJA yaitu sebesar 16,08. Penelitian ini sejalan dengan penelitian (Rizany, 2019) didapatkan hasil perbandingan waktu tunggu pada pasien online dan pasien offline mengatakan bahwa terdapat perbedaan antara waktu tunggu pasien online dengan pasien offline ( $p$-value $=0,0001)$. Berdasarkan penelitian (Dewi, 2015) menyatakan waktu tunggu yang cepat cenderung meningkatkan kepuasan pasien terhadap pelayanan dan lamanya waktu tunggu dapat menurunkan tingkat kepuasan pasien.

Peneliti telah melakukan hasil analisis data menggunakan Uji statistik Uji $\mathrm{T}$ yang menunjukkan terdapat perbandingan waktu tunggu pasien rawat jalan yaitu antara pasien online dan pasien offline menunjukan hasil yang signifikan $(p=0,003)$ berarti ada perbedaan waktu tunggu pelayanan yang signifikan antara kelompok pasien online dan kelompok pasien offline. Dari hasil 
penelitian didapatkan selisih perbandingan waktu tunggu pasien rawat jalan di RSUD Ratu Zalecha Martapura antara pasien online dan pasien offline yaitu 116 menit. Pada pasien pendaftran online didapatkan waktu tunggu yang lebih cepat dikarenakan pada pasien online setelah pasien sampai pada mesin APM dan melakukan verifikasi barcode pasien akan langsung menuju ke Poli tujuan berobat dan tidak perlu menunggu nomor antrian dipanggil di loket.

Penelitian ini sejalan dengan penelitian (Laeliyah \& Subekti, n.d.) didapatkan hasil bahwa lamanya waktu menunggu pelayanan pasien di IRJA $>60$ menit 49 orang sebesar 70,18 menit. Penelitian ini sejalan dengan (Dewi, 2015) berdasarkan perhitungan uji chi square didapatkan $(p=0,000)$ maknanya terdapat kecenderungan terhadap lekasnya waktu tunggu di pendaftaran meningkatkan kepuasan terhadap pelayanan, atau waktu tunggu yang lama di pendaftaran menurunkan tingkat kepuasan terhadap penyediaan jasa. Hasil penelitian ini sejalan dengan penelitian (Ernawati et al., 2018) didapatkan hasil bahwa terdapat hubungan kepuasan dengan lamanya waktu tunggu $(p=0,046)$. Semakin baik pelayanan yang diberikan dan waktu tunggu yang baik maka kepuasan pasien semakin meningkat.

\section{Simpulan dan Saran}

Simpulan dari penelitian ini yaitu terdapat perbedaan kepuasan pasien di IRJA RSUD Ratu Zalecha ( $p=0,001)$. Dan didapatkan perbedaan waktu tunggu pasien di IRJA RSUD Ratu Zalecha ( $p=0,003)$.

Hasil dari penelitian ini diharapkan rumah sakit dapat mengimplementasikan pendaftaran online secara optimal dan bisa mengevaluasi secara rutin. Meningkatkan pelayanan yang optimal sehingga dapat meningkatkan kepuasan pasien dan meminimalkan waktu tunggu pasien.

\section{Daftar Pustaka}

Anggrianni, S., Adji, I. S., Mustofa, A., \& Wajdi, M. F. (2016). Kepuasan Pasien Rawat Inap Dan Rawat Jalan Terhadap Pelayanan Gizi Pasien Diet Diabetes Melitus. Jurnal Ekonomi Manajemen Sumber Daya, 19.

Ar-rasily, O. K., \& Dewi, P. K. (2016). Faktor-Faktor Yang Mempengaruhi Tingkat Pengetahuan Orang Tua Mengenai Kelainan Genetik Penyebab Disabilitas Intelektual Di Kota Semarang. Jurnal Kedokteran Diponegoro, 5(4), 1422-1433.

Dewi, A. U. (2015). Hubungan Waktu Tunggu Pendaftaran Dengan Kepuasan Pasien Di Tempat Pendaftaran Pasien Rawat Jalan (TPPRJ) RSUD Sukoharjo. Program studi kesehatan masyarakat fakultas ilmu kesehatan universitas muhammadiyah surakarta.

Ernawati, E., Pertiwiwati, E., Setiawan, H., Studi, P., Keperawatan, I., Kedokteran, F., \& Lambung, U. (2018). Waktu Tunggu Pelayanan Rawat Jalan Dengan Tingkat Kepuasan Pasien. 1(April), 1-10. 
Guyton, A. C. \&. (2004). Buku Ajar Fisiologis Kedokteran.

Kemenkes, 2008. (n.d.). Kementrian Kesehatan RI, 2008, Keputusan Kesehatan RI Nomor 129/MENKES/SK/II2008 tentang Standar Pelayanan Minimal Rumah Sakit.

Kuntoro, W., \& Istiono. (2017). Kepuasan Pasien Terhadap Kualitas Pelayanan di Tempat Pendaftaran Pasien Rawat Jalan Puskesmas Kretek Bantul Yogyakarta. Jurnal Kesehatan Vokasional, 2(pp.14047.).

Laeliyah, N., \& Subekti, H. (n.d.). Waktu Tunggu Pelayanan Rawat Jalan dengan Kepuasan Pasien Terhadap Pelayanan di Rawat Jalan RSUD Kabupaten Indramayu. 1(2), 102112.

Listiani, I. (2017). Hubungan Tingkat Pendidikan Penghasilan Pasien Dengan Persepsi Pasien Tentang Mutu Pelayanan Kesehatan Di Puskesmas Baki Kabupaten Sukoharjo. Fakultas Ilmu Kesehatan Universitas Muhammadiyah Surakarta, 3(1), 87. https://doi.org/10.1017/CB09781 107415324.004

Munawir, I. (2018). Faktor-faktor yang Berhubungan dengan Kepuasan Pasien Rawat Jalan Rumah Sakit. Jurnal Ilmiah Kesehatan, Vol.17 No.3 Tahun 2018, 17, 15-22.

Muninjaya, A. . G. (2011). Manajemen Kesehatan.

Permana, A. A. (2018). Evaluasi Waktu Tunggu Dan Kepuasan Pelayanan Pada Pasien Rawat Jalan Di RSUD Dr. Loekmono Hadi Kudus Periode Februari - April 2018. April.

Pranatha, A., Sudirman, R. M., \& Sari, N. N.
(2018). Faktor-Faktor Yang Berhubungan Dengan Kepuasan Pasien Terhadap Pelayanan Keperawatan Di Puskesmas Rawat Inap Se-Kabupaten Kuningan Tahun 2017. 1, 1-9.

Rensiner, Azwar, V. Y., \& Putra, A. S. (2018). Analisis Faktor Kualitas Pelayanan Terhadap Kepuasan Pasien Rawat Jalan RSUD DR. Achmad Darwis. Jurnal Kesehatan Andalas 2018;7, 1-8.

Rizany, I. (2019). Efektivitas Pendaftaraan Online Terhadap Waktu Tunggu Dan Kepuasan Pasien Di Rawat Jalan Di Rsud Ulin Dan Rsdi Banjarbaru. PSIK FK Universitas Lambung Mangkurat.

Stefan, M. M., Redjeki, G. S., \& Susilo, W. H. (2013). Hubungan Karakteristik Pasien Dengan Kepuasan Pasien Terhadap Mutu Pelayanan Kesehatan di Puskesmas Kecamatan Pesanggrahan Jakarta Selatan.

Supartiningsih, S. (2017). Kualitas Pelayanan an Kepuasan Pasien Rumah Sakit: Kasus Pada Pasien Rawat Jalan. Jurnal Medicoeticolegal Dan Manajemen Rumah Sakit 10.18196/Jmmr.2016, 6(1), 9-15. https://doi.org/10.18196/jmmr.6 122

Suwaryo, P. A. W., \& Yuwono, P. (2017). Faktor-Faktor Yang Mempengaruhi Tingkat Pengetahuan Masyarakat dalam Mitigasi Bencana Alam Tanah Longsor. 2407-9189, 305314.

Uma, H. (2017). Pengaruh perbedaan jenis kelamin terhadap penyesuaian diri mahasiswa internasional di uin malang. 